\title{
Pemanfaatan Bahan Makanan Tradisional Tempe Kedelai Sebagai Menu Andalan Hotel
}

\author{
(Studi Kasus : Jadul Village Resort \& Spa, Bandung) \\ Swastono Putro Pirastyo \\ Akademi Pariwisata Nasional Indonesia (AKPARINDO Bandung) \\ Swastono.putro@gmail.com \\ Yuliana Pinaringsih Kristiutami \\ Akademi Pariwisata BSI Bandung \\ Yuliana.ylp@bsi.ac.id
}

\begin{abstract}
Tempe is one famous traditional food from Indonesia. Tempe can be process into so many variety of food with delicious taste. But in hospitality industries, the utilization of tempe is not maximal yet. This research is to find out the utilization of tempe in Jadul Village Resort and Spa. This research is also wanted to find how often tempe used in the menu, and how good the demand of the tempe itself. After this research, hopefully tempe can used more often as the main course menu, or as side dishes. And hopefully, tempe can dreated into signature dishes that represent Jadul Village Resort and Spa as a resort with the Indonesian specialty.
\end{abstract}

Keywords - tempe; utilization; traditional food

Abstrak- Tempe adalah salah satu makanan tradisional yang terkenal yang berasal dari Indonesia. Tempe dapat diolah menjadi beraneka ragam jenis makanan dengan rasa yang lezat. Namun pemanfaatannya di industry pariwisata belumlah maksimal. Penelitian ini bertujuan untuk menemukan pemanfaatan tempe di Jadul Village Resort and Spa. Penelitian ini juga ingin mencari tahu seberapa sering bahan dasar tempe digunakan dalam menu, serta seberapa baik permintaan akan tempe itu sendiri. Setelah dilaksanakannya penelitian ini, diharapkan tempe dapat digunakan lebih sering lagi sebagai menu utama atau sebagai makanan pendamping. Diharapkan juga tempe dapat dikreasikan menjadi makanan unggulan yang merepresentasikan citra Jadul Village Resort and Spa sebagai hotel dengan keunikan Indonesia.

Kata kunci-tempe; pemanfaatan; makanan tradisional

\section{PENDAhUluan}

Berbicara mengenai pariwisata dan daerah tujuan wisata, tentunya kita tidak dapat melewatkan Kota Bandung. Kota Bandung terkenal dengan berbagai inovasi dan kreasi yang dapat memanjakan wisatawan yang berkunjung ke kota kembang tersebut. Dari tingkat kunjungan wisatawan, kota ini tercatat sebagai salah satu kota dengan tingkat kunjungan yang cukup besar. Tercatat 4.418.781 orang datang mengunjungi Kota Bandung di tahun 2015, yang 176.487 orang diantaranya merupakan wisatawan manca Negara (Bandung Dalam Angka, 2016: 170).

Perkembangan kepariwisataan Kota Bandung tentu tidak terlepas dari sumbangsih popularitas makanan dan minuman yang diperjual belikan di daerah ini. Berbagai macam olahan dipadukan dengan aneka ragam bahan dasar menghasilkan kreasi makanan dan minuman yang menarik, yang tentunya dapat meningkatkan kunjungan wisatawan. Industri makanan dan minuman secara tidak langsung turut menjadi salah satu motor penggerak perekonomian mikro di daerah tujuan wisata.

Kota Bandung terkenal dengan berbagai macam olahan tepung aci (sagu) yang dapat dikreasikan menjadi berbagai jenis olahan. Rasa yang unik, harga yang terjangkau, serta berbagai inovasi yang disematkan menjadi magnet penarik minat calon pembeli jajanan tersebut. Disamping olahan aci, bahan dasar tradisional juga dapat dijadikan salah satu pilihan bagi produsen untuk dapat berkreasi dan mengembangkan olahan kuliner yang berkualitas. Salah satu bahan dasar tradisional Indonesia yang sudah melegenda, yang dapat dikembangkan menjadi aneka olahan andalan yaitu Tempe.

Pada saat ini pemanfaatan tempe sebagai bahan dasar utama untuk menghasilkan produk inovatif dan memiliki nilai jual tinggi masih minim dilakukan. Penelitian terdahulu mengenai pemanfaatan tempe sebagai menu andalan juga tidak ditemukan. Penggunaan 
bahan dasar ini di hotel-hotel besar juga masih sebagai makanan pendamping (side dishes).

Padahal tempe memiliki potensi yang baik, cara pengolahan yang mudah, ketersediaan bahan baku melimpah, dan juga harga yang murah. Namun potensi dan kelebihan tersebut sepertinya belum dimanfaatkan secara maksimal untuk menghasilkan sebuah makanan ikonik dengan nilai jual tinggi.

Hal inilah yang menimbulkan ketertarikan peneliti untuk dapat mencari tahu seberapa besar pemanfaatan tempe di hotel, dan bagaimana bentuk pemanfaatan bahan dasar tersebut pada menu yang disajikan di hotel.

Penelitian dilaksanakan di Jadul Village Resort and Spa, Bandung. Lokasi ini dipilih karena Jadul Village Resort and Spa merupakan salah satu resort yang memiliki konsep tradisional, dengan nuansa dan atmosfir tradisional dan lengkap dengan menu-menu masakan Indonesia sebagai menu andalan.

Berdasarkan latar belakang masalah diatas, peneliti mengidentifikasi beberapa permasalahan, yaitu:

1. Pemanfaatan tempe masih sangat terbatas.

2. Ragam menu yang dihasilkan dengan bahan dasar tempe masih terbatas.

3. Tempe belum diolah dan disajikan sebagai makanan yang memiliki nilai jual tinggi.

Tujuan dilakukannya penelitian ini adalah sebagai berikut:

1. Mencari tahu bagaimana bentuk pemanfaatan tempe di hotel.

2. Mencari tahu bagaimana bentuk menu yang menggunakan bahan dasar tempe, dan berapa banyak jumlahnya (Jika dibandingkan dengan total jumlah menu yang terdapat di hotel tersebut).

3. Mencari tahu, apakah tempe sudah dimanfaatkan dan diolah sehingga memiliki nilai jual tinggi dan menjadi andalan suatu hotel.

Manfaat dari penelitian ini adalah untuk mendorong dan merekomendasikan pemanfaatan bahan dasar tradisional tempe ke level yang lebih tinggi. Sehingga pemanfaatan tempe tidak hanya sekedar sebagai menu pelengkap maupun snek, namun dapat diolah sebagai menu andalan.

Melalui pemanfaatan tempe di level hotel, diharapkan tempe dapat semakin dikenal, baik oleh wisatawan nusantara maupun wisatawan asing. Efek berlapis (multiplier effect) juga diharapkan timbul dari peningkatan pemanfaatan Tempe pada level hotel, adalah produktivitas pengrajin Tempe meningkat yang didukung pula oleh kualitas tempe yang juga dapat meningkat.

\section{KAJIAN PUSTAKA}

\section{A. Menu}

Menu adalah sebuah sarana untuk menginformasikan produk makan dan minum yang akan kita jual kepada pelanggan/tamu (Heru, Anwari dan Budi, 2011:1). Menurut Ardjuno (2008: 88) yang dimaksud dengan menu adalah daftar makanan yang terdiri dari makanan untuk makan pagi, makan siang, makan malam, dan snack, juga tercantum daftar minuman dan/atau wine.

Dapat dikatakan bahwa menu merupakan media komunikasi utama antara tamu dengan pihak restoran. Melalui menu, setidaknya seorang tamu akan mendapatkan informasi mengenai makanan dan minuman apa saja yang disediakan oleh suatu restoran, bahan dasar yang digunakan di dalam suatu makanan, maupun cara pengolahan suatu makanan tersebut.

Disamping berfungsi sebagai daftar makanan dan minuman yang dijual, menu juga berfungsi sebagai salah satu sarana pemasaran. The menu must be coordinated with and seek to further the goals of the marketing concept. (Jones dan Merricks, 2006 :46). Dengan kata lain, menu juga memiliki fungsi sebagai perpanjangan tangan dari bagian pemasaran. Menu juga dapat mencerminkan gaya maupun spesialisasi yang dipilih suatu restoran.

Sebagai salah satu alat pemasaran, tentunya menu harus dapat mempengaruhi konsumen untuk melakukan pembelian. The menu should act as a means to influence customer demand for menu items. (Jones dan Merricks, 2006 :46). Hal ini dapat dilakukan, apabila suatu menu ditata dengan apik, menarik dan mudah dimengerti. Oleh sebab itu, tidak jarang pemilik usaha berusaha membuat menu sekreatif dan semenarik mungkin. Karena peranan sebuah menu sangat penting untuk memberikan image/persepsi kepada tamu (Heru, Anwari dan Budi, 2011:4).

Bagi manajemen, menu juga memiliki fungsi yang penting. Selain sebagai sarana pemasaran, melalui menu secara tidak langsung manajemen dapat menentukan ruang lingkup organisasi, kebutuhan sumber daya manusia, jenis peralatan dan perlengkapan yang diperlukan serta jenis makanan yang dibutuhkan. Menu yang baik menurut Heru, Anwari dan Budi, (2011:9) adalah menu yang keterlangsungan produknya dapat terjamin dengan baik, hal ini menunjukkan komitmen 
dan profesionalisme yang baik di dalam menangani sebuah menu dalam restoran.

Berdasarkan hal inilah, maka pemilihan bahan dasar tempe sebagai bahan olahan utama di dalam menu dapat dipertimbangkan. Karena tempe mampu memenuhi salah satu syarat kriteria menu yang baik yaitu bahan baku yang melimpah yang dapat menjamin keterlangsungan menu tersebut.

\section{B. Tempe}

Tempe merupakan makanan yang terbuat dari biji kedelai atau beberapa bahan lain yang diproses melalui fermentasi dari apa yang secara umum dikenal sebagai "ragi tempe" (Tempe: Persembahan Indonesia Untuk Dunia, 2012: 1). Bahan yang tercipta setelah proses peragian inilah yang dikenal orang sebagai tempe. Indonesia sendiri mengenal berbagai macam jenis tempe. Tempe bungkil di daerah Klaten (Jawa Tengah), tempe benguk di Yogyakarta, tempe enjes di Malang, Kediri dan beberapa daerah di Jawa Timur, dan tempe kecipir di Sumenep (Lies, 2007:24). Dari sekian banyak jenis tempe, tempe yang paling familiar tentunya adalah tempe kedelai.

Tempe menjadi salah satu bahan pangan yang menjadi ciri khas bahan makanan yang sangat Indonesia. Awalnya, tempe identik dengan masyarakat Jawa Tengah. Namun seiring dengan penyebaran masyarakat jawa ke berbagai daerah di penjuru Indonesia, tempe dibawa serta sehingga saat ini hampir di seluruh daerah di Indonesia mengenal dan mengkonsumsi tempe. Indonesia merupakan negara produsen tempe terbesar di dunia. Konsumsi tempe rata-rata per orang per tahun di Indonesia saat ini diperkirakan mencapai sekitar 6,45 kg. (Tempe: Persembahan Indonesia Untuk Dunia, 2012: 2). Namun sayang, di level internasional tempe terlebih dahulu dipatenkan oleh Jepang.

\section{Kandungan Zat Gizi Tempe}

Untuk dapat dipopulerkan lebih jauh, tentunya suatu bahan makanan haruslah memiliki kandungan gizi yang baik. Melalui kandungan gizi yang terdapat di dalam suatu bahan makanan diharapkan masyarakat dapat sadar dan berujung pada peningkatan tingkat konsumsi bahan makanan tersebut.

Berdasarkan data yang penulis dapatkan, berikut ini adalah rangkuman nilai gizi yang terkandung dalam tempe.
TABEL 1. KANDUngan ZAT GiJI TEMPE

\begin{tabular}{|c|c|c|c|}
\hline \multirow[b]{2}{*}{ No } & \multicolumn{3}{|c|}{ Kandungan Zat Gizi Tempe } \\
\hline & Zat Gizi & Satuan & $\begin{array}{c}\text { Komposisi } \\
\text { zat gizi } \\
100 \text { gram } \\
\text { BDD } \\
\end{array}$ \\
\hline 1. & Energi & Kal & 201 \\
\hline 2. & Protein & Gram & 20,8 \\
\hline 3. & Lemak & Gram & 8,8 \\
\hline 4. & Hidrat Arang & Gram & 13,5 \\
\hline 5. & Serat & Gram & 1,4 \\
\hline 6. & $\mathrm{Abu}$ & Gram & 1,6 \\
\hline 7. & Kalsium & $\mathrm{Mg}$ & 155 \\
\hline 8. & Fosfor & $\mathrm{Mg}$ & 326 \\
\hline 9. & Besi & $\mathrm{Mg}$ & 4 \\
\hline 10. & Karotin & Mkg & 34 \\
\hline 11. & Vitamin B1 & $\mathrm{Mg}$ & 0,19 \\
\hline 12. & Air & Gram & 55,3 \\
\hline 13. & BDD* & $(\%)$ & 100 \\
\hline $\begin{array}{l}\text { Sumbe } \\
\text { Bin. G } \\
\text { Indone }\end{array}$ & $\begin{array}{l}\text { Komposisi Zat Gizi Pa } \\
\text { Masyarakat dan Puslit } \\
\text { Untuk Dunia, 2012. }\end{array}$ & $\begin{array}{l}\text { Departeme } \\
\text { dalam Te }\end{array}$ & $\begin{array}{l}\text { sehatan RI Dir. } \\
\text { Persembahan }\end{array}$ \\
\hline
\end{tabular}

\section{Olahan Berbahan Dasar Tempe}

Bahan dasar tempe seringkali hanya diolah sebagai bahan pelengkap di dalam olahan sayuran. Disamping hanya sebagai bahan pelengkap, tempe juga seringkali disajikan sebagai bahan makanan ringan pendamping minum teh, sebagai tempe mendoan misalnya.

Variasi makanan yang dikembangkan berdasarkan bahan dasar tempe juga tidak terlalu banyak ditemui dipasaran. Beberapa jenis variasi olahan tersebut antara lain steak tempe lada hitam, burger tempe, bakso tempe, sushi tempe, rolade tempe, maupun bola tempe (Hipwee.com).

Meskipun dapat diolah menjadi berbagai jenis makanan yang menggugah selera, nyatanya penerapan variasi dalam pengolahan tempe sebagai bahan sajian yang istimewa ternyata masih jauh dari harapan. Inovasi olahan berbahan dasar tempe yang dapat diterima oleh masyarakat dan menjadi populer adalah berupa olahan keripik tempe. Bahkan, olahan keripik dengan menggunakan bahan dasar tempe juga sudah dikemas dengan modern, dan dijadikan cemilan populer yang disukai berbagai kalangan.

Dibalik sekilas kesuksesan tempe dengan inovasi keripiknya, tempe seperti terjebak di dalam takdirnya sendiri. Takdir yang tergaris sebagai makanan rakyat jelata. Bahkan seperti tidak kuasa melawan takdir, nasib tempe pada akhirnya tidak dapat melepas unsur kesederhanaannya. Paradigma inilah yang mungkin membuat tempe tidak diolah dan disajikan dengan lebih baik dan seolah kekal tersaji hanya sebagai makanan pendamping saja. 


\section{Metode PENELITIAN}

\section{A. Waktu dan Tempat Penelitian}

Penelitian dilakukan di Jadul Village Resort and Spa yang beralamat di jalan Terusan Sersan Bajuri, No. 45, Cihideung, Parompong, Kab. Bandung Barat, Jawa Barat. Waktu penelitian dilaksanakan pada bulan Februari 2018.

\section{B. Rancangan Penelitian}

Penelitian dirancang dengan menggunakan pendekatan eksploratif. Dimana pendekatan eksploratif digunakan untuk dapat mencari tahu, bagaimana bentuk pemanfaatan tempe sebagai bahan dasar olahan makanan yang tercermin dari menu makanan yang terdapat di Jadul Village Resort and Spa. Melalui pendekatan ini, diharapkan juga dapat mencari tahu, bagaimana popularitas tempe pada menu di Jadul Village Resort and Spa.

\section{Teknik Pengempulan Data}

1. Data Primer

Sekaran (2006:61) menuturkan beberapa contoh sumber data primer adalah responden individu, kelompok fokus, dan panel yang secara khusus ditentukan oleh peneliti. Data primer penelitian ini adalah informasi yang di dapatkan dari pelaksanaan wawancara terhadap chef dan general manager Jadul Village Resort and Spa.

\section{Data Sekunder}

Data sekunder didapatkan dari data berbagai dokumen yang terkait dengan informasi pemanfaatan tempe, seperti menu, daftar pilihan makanan buffet, dan berbagai dokumen terkait lainnya.

\section{Instrumen Penelitian}

Untuk mendapatkan hasil penelitian yang seakurat mungkin, penulis menggunakan instrumen penelitian sebagai berikut:

1. Wawancara

Wawancara adalah merupakan pertemuan dua orang untuk bertukar informasi dan ide melalui tanya jawab, ... (Sugiyono, 2014:72). Teknik wawancara digunakan untuk mengetahui berbagai informasi dari responden secara lebih mendalam.

2. Observasi

Menurut Sutrisno (dalam Suiyono, 2014: 145) observasi adalah suatu proses yang kompleks, suatu proses yang tersusun dari berbagai proses biologis dan psikologis. Observasi dilakukan terhadap daftar menu serta terhadap berbagai pilihan pesanan makanan yang tamu lakukan selama menginap di Jadul Village Resort and Spa.
3. Dokumentasi

Dokumentasi adalah penyelidikan yang dilakukan terhadap berbagai macam dokumen pendukung.

\section{E. Metode Analisis Data}

Metode yang akan digunakan adalah berupa metode penelitian kualitatif. Sugiyono (2014:1) menyampaikan bahwa metode penelitian kualitatif adalah metode penelitian yang digunakan untuk meneliti pada kondisi obyek yang alamiah, ... dimana peneliti adalah sebagai instrumen kunci, teknik pengumpulan data dilakukan secara trianggulasi (gabungan), analisis data bersifat induktif, dan hasil penelitian kualitatif lebih menekankan makna dari pada generalisasi.

Disampaikan pula oleh Sugiyono (2014:3) bahwa dalam penelitian kualitatif, pengumpulan data tidak dipandu oleh teori, tetapi dipandu oleh fakta-fakta yang ditemukan pada saat penelitian di lapangan.

Analisis data adalah proses mencari dan menyusun secara sistematis data yang diperoleh dari hasil wawancara, catatan lapangan, dan dokumentasi, ..., memilih mana yang penting dan yang akan dipelajari, dan membuat kesimpulan, ... (Sugiyono, 2014:89).

Proses analisa data dilakukan sebagai berikut :

1. Melakukan pencatatan berbagai data yang didapatkan dari lapangan, baik yang berupa data primer maupun data sekunder.

2. Mengumpulkan data dan melakukan seleksi serta melakukan pemilahan data untuk selanjutnya melakukan klasifikasi dan membuat ringkasan atau ikhtisar dari semua data tersebut.

3. Menganalisa data yang didapat, dan mencari hubungan serta pola yang tersusun dari kumpulan data tersebut, untuk selanjutnya disusun menjadi sebuah kesimpulan umum.

Berdasarkan pada instrumen penelitian dan teknik analisis data yang telah ditetapkan sebelumnya, maka penelitian ini akan dilakukan berdasarkan pada tahapan-tahapan berikut ini:

1. Melakukan studi dan pengamatan terhadap menu dan berbagai pilihan olahan makanan yang terdapat di Jadul Village Resort and Spa. Studi ini bertujuan untuk memperoleh gambaran umum mengenai jenis makanan apa saja yang ditawarkan oleh Jadul Village Resort and Spa kepada tamu.

2. Berdasarkan hasil studi dan pengamatan tersebut, peneliti dapat menyusun kerangka 
penelitian serta memilih instrumen penelitian yang tepat.

3. Melakukan wawancara terhadap chef dan general manager mengenai menu dan juga bentuk pemanfaatan bahan dasar tempe dalam menu yang digunakan.

4. Mengumpulkan data sekunder dari berbagai dokumen pendukung seperti menu buffet list, banquet event order, dan sebagainya.

5. Melakukan analisa data, serta menyusun kesimpulan dan rekomendasi.

\section{HASIl PENELITIAN DAN PEMBAHASAN}

Jadul Village Resort and Spa, sebagai resort yang memiliki konsep tradisional Indonesia memiliki beberapa jenis menu yang ditawarkan kepada para tamu. Menu Ala Carte ditawarkan bagi tamu yang ingin memesan makanan di restoran maupun melalui pelayanan kamar. Menu Table D'hote atau set menu, ditawarkan kepada tamu yang menyelenggarakan acaraacara khusus, seperti resepsi pernikahan, rapat dan sebagainya. Tersedia juga menu spesial yang dikreasikan khusus untuk perayaan momen-momen tertentu, seperti Honeymoon Package.

Berikut ini penulis tampilkan foto daftar makanan yang berhasil penulis dapatkan:

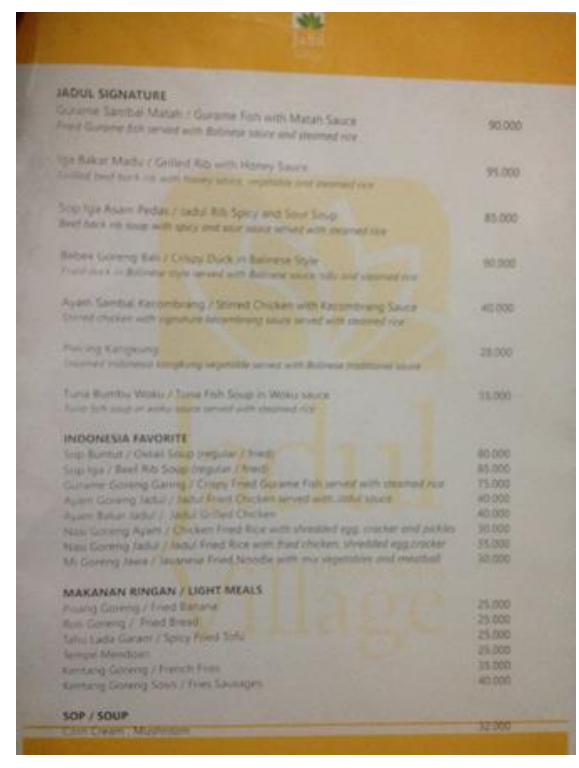

Sumber : Dokumentasi Penulis

\section{GAMBAR 1. MENU ALA CARTE}

Pada gambar 1, dapat terlihat bahwa pilihan makanan yang tersedia di Jadul Village Resort and Spa merupakan berbagai pilihan olahan makanan khas Indonesia. Menurut penuturan Chef Luke Januar, sebagai Chef Jadul Village Resort and Spa, menu ala carte yang saat ini digunakan merupakan menu sementara yang disusun untuk dapat mengakomodir adanya rencana perubahan jangka panjang yang saat ini tengah dipersiapkan.

Merujuk pada gambar 1, terdapat 22 macam pilihan pada menu ala carte. Dapat terlihat bahwa pemanfaatan tempe sebagai bahan olahan hanya terdapat pada 1 jenis menu, yaitu Tempe Mendoan pada kategori makanan ringan. Pada menu lainnya, baik itu kategori Jadul Signature, Indonesian Favourite, maupun Soup, tidak tampak adanya keterangan pemanfaatan tempe sebagai bahan dasar maupun bahan pelengkap penyajian. Lebih lanjut, Chef Luke juga menyampaikan bahwa penggunaan tempe juga seringkali hanya digunakan sebagai side dishes atau hidangan pendamping.

Untuk daftar makanan yang dapat dipilih sebagai menu table dhote, Jadul Village Resort and Spa menyediakan berbagai macam olahan makanan yang tidak hanya terbatas pada menu olahan khas Indonesia. Tercatat terdapat 261 macam jenis makanan yang dapat dipilih oleh tamu. Pilihan tersebut terdiri dari 35 macam pilihan sup, 42 macam pilihan olahan daging, 48 macam pilihan olahan ayam dan bebek, 65 macam pilihan olahan ikan dan seafood, 46 macam pilihan sayuran, 5 macam pilihan olahan telur, dan 20 macam pilihan gorengan.

Dari total 261 macam pilihan makanan yang dapat dipilih, hanya terdapat 5 jenis makanan yang menggunakan bahan utama tempe. 5 jenis makanan tersebut adalah Oseng Tempe Cabe Hijau, Tempe Bacem, Tempe Goreng, Tempe Goreng Kering, dan Tempe Mendoan. Jenis makanan lain yang mungkin menggunakan tempe sebagai salah satu bahan olahan maupun bahan pelengkap tidak dapat penulis identifikasi lebih lanjut.

Prosentase penggunaan tempe dalam menu yang ditawarkan masih sangat sedikit. Pada menu ala card, prosentase penggunaan tempe hanya sebesar $4,54 \%$ dari total keseluruhan menu. Sementara untuk pilihan makanan pada menu table dhote, prosentase penggunaan tempe sebagai bahan dasar hanya sebesar $1,91 \%$.

Pemanfaatan tempe sebagai salah satu bahan dasar yang sangat Indonesia masih kalah dibandingkan dengan saudara dekatnya, tahu. Pada menu ala card, prosentase penggunaan bahan dasar tahu sebagai bahan olahan adalah $4,54 \%$. Sedangkan dalam pilihan menu table dhote, tercatat 20 jenis makanan yang memanfaatkan tahu sebagai bahan dasar, atau sebesar 7,66\%.

Sementara itu, pemanfaatan tempe dan tahu untuk menu spesial tidak dapat penulis temukan. 
Tabel 2. Prosentase PemanfaAtan Tempe Dalam MENU

\begin{tabular}{llcc}
\hline \multirow{2}{*}{ No } & \multicolumn{3}{c}{ Prosentase Pemanfaatan Tempe } \\
\cline { 2 - 4 } & \multicolumn{1}{c}{ Jenis Menu } & Tempe & Tahu \\
\hline 1. & Ala Card & $4,54 \%$ & $4,54 \%$ \\
2. & Table Dhote & $1,91 \%$ & $7,66 \%$ \\
3. & Special Menu & $0 \%$ & $0 \%$ \\
\hline Sumber: Pengolahan Data Penulis & \multicolumn{3}{c}{}
\end{tabular}

Berdasarkan tabel 2, dapat terlihat dengan jelas bagaimana prosentase pemanfaatan tempe sebagai bahan olahan yang digunakan di Jadul Village Resort and Spa ternyata masih lebih kecil dibandingkan dengan pemanfaatan tahu, yang notabene merupakan sama-sama hasil olahan kedelai.

\section{KESIMPULAN}

Melalui hasil observasi dan wawancara yang penulis lakukan, ditemukan fakta bahwa tempe memang tidak terlalu familiar digunakan di lingkungan hotel. Pemanfaatan tempe menjadi bahan makanan yang memiliki potensi hasil olahan yang beragam dan memiliki nilai jual tinggi juga belum dapat penulis temukan.

Penulis juga menemukan fakta lain mengenai pemanfaatan tempe. Melalui wawancara kepada chef Jadul Village Resort and Spa, penulis menemukan fakta bahwa pada dasarnya minat tamu terhadap bahan dasar tempe sangat rendah. Bahkan menu Tempe Mendoan yang menjadi satu-satunya bentuk pemanfaatan tempe pada menu ala carte juga tidak memiliki daya jual yang baik.

Dengan demikian, melalui berbagai data dan fakta yang penulis temukan dilapangan, penulis dapat menyimpulkan bahwa pemanfaatan tempe sebagai menu andalan belum dilakukan secara maksimal.

Pengembangan kreasi menu dari bahan olahan tempe urung dilakukan karena memang permintaan menu dengan bahan dasar tempe sangat rendah. Maka, upaya pengembangan dan pemanfaatan tempe sebagai bahan olahan yang lebih variatif pun dirasa tidak akan berpengaruh maksimal.

Walaupun Jadul Village Resort and Spa merupakan resort yang menawarkan kekhasan nuansa Indonesia, namun pada kenyataannya tamu yang menginap di resort ini sebagian besar merupakan wisatawan asing. Hal inilah yang sepertinya membuat tempe menjadi sulit untuk mendapat tempat lebih spesial. Karena bagi kebanyakan tamu yang berasal dari luar negeri, tempe bukanlah bahan makanan yang familiar.

Walaupun begitu, penulis merasa bahwa tempe dapat dicoba untuk diperkenalkan lebih jauh melalui cara-cara yang sederhana. Harapannya, tempe dapat diperkenalkan melalui penggunaan tempe sebagai side dishes andalan yang dapat menyatu dengan berbagai jenis masakan Indonesia. Diharapkan pula, chef dapat menyusun sebuah menu khas olahan tempe yang berisi berbagai kreasi olahan tempe kekinian. Dengan harapan bahwa melalui ragam kreasi dan olahan tempe, wisatawan dapat tertarik untuk mencoba menu tempe tersebut sehingga tempe dapat menjadi populer dan dapat diposisikan sebagai menu andalan Jadul Villager Resort and Spa.

\section{DAFTAR RUJUKAN}

Ardjuno W. (2008). Pengetahuan Tata Hidang. Jakarta: Penerbit Erlangga.

Heru R., Anwari M., \& Budi W. (2011). Pengetahuan Menu. Bandung: Alfabeta.

Jones, P. \& Merricks, P. (2006). The Management of Foodservice Operation. London: Thompson Learning.

Kota Bandung Dalam Angka 2016. BPS Kota Bandung.

Sekaran, Uma. (2006). Motodologi Penelitian untuk Bisnis, Edisi 4, Buku 2. Jakarta: Salemba Empat.

Sugiyono. (2014). Memahami Penelitian Kualitatif. Bandung: Alfabeta, CV.

Tempe: Persembahan Indonesia Untuk Dunia. 2012. Jakarta: Badan Standarisasi Nasional.

Lies S. (2007). Pembuatan Tempe. Yogyakarta: Penerbit Kanisius.

8 Kreasi Resep Tempe Kekinian Yang Rasanya Kayak Menu Restoran, Tips (2017), Hipwee, Diakses tanggal 12 Februari, 2018, dari https://www.hipwee.com/tips/8-kreasiresep-tempe-kekinian-yang-rasanyakayak-menu-restoran. 